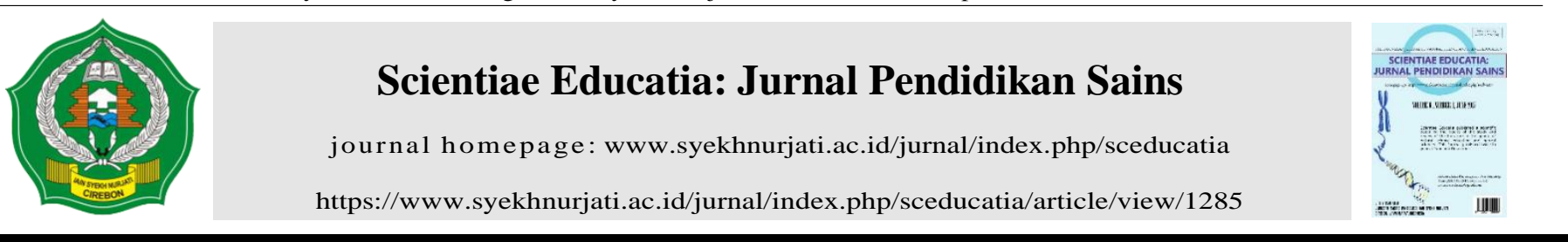

\title{
Jenis Herpetofauna Di Cagar Alam Dan Taman Wisata Alam Pengandaran Jawa Barat
}

\author{
Syafa'at Ariful Huda \\ Program Studi Pendidikan Matematika, STKIP Kusumanegara

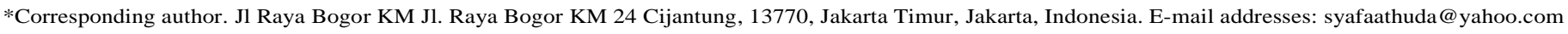

a r t ic 1 e i n f o

Article history:

Received 26 January 2017

Received in revised form 15 April

2017

Accepted 14 June 2017

Available online June 2017

\section{Keywords:}

cikamal

cirengganis

herpetofauna

Kata Kunci:

cikamal

cirengganis

herpetofauna a b s t r a c t

This study aims to determine the type of Herpetofauna that often appear in the area Cikamal and Cirengganis. This research was conducted in West Java precisely in Nature Tourism and Pangandaran Nature Reserve. The method used in this research is descriptive qualitative with field research approach (VES). Visual Encounter Survey (VES) along the river and river body. The data obtained is analyzed first with the calculation of the number and calculation of the percentage of research results. From the results of this study get 2 types of herpetofauna consisting of amphibians and reptiles. Amphibians consist of a type of frog and type of bangkong. While only the type of lizard reptile found in the two locations. Amphibians and reptiles are found: Type of frog (Fajervarya limnocharis, Rana chalconata, Microdiscus sp, Hylidae), type of bangkong (Microhyla achatina, Bufonidae) and Lizard Type (Spenomorphus sp).

Penelitian ini bertujuan untuk mengetahui jenis Herpetofauna yang sering muncul di daerah Cikamal dan Cirengganis. Penelitian ini dilakukan di Jawa Barat tepatnya di Wisata Alam dan Cagar Alam Pangandaran. Metode yang digunakan dalam penelitian adalah deskriptif kualitatif dengan pendekatan riset lapangan (VES). Visual Encounter Survey (VES) dengan menyusuri Sungai dan badan Sungai. Data yang diperoleh dianalisis terlebih dahulu dengan perhitungan jumlah dan perhitungan persentase hasil penelitian. Dari hasil penelitian kali ini mendapatkan 2 jenis herpetofauna yang terdiri dari amfibi dan reptil. Amfibi terdiri dari jenis katak dan jenis bangkong. Sedangkan reptil hanya jenis kadal yang di temukan di dua lokasi tersebut. Amfibi dan reptil yang ditemukan yaitu: Jenis katak (Fajervarya limnocharis, Rana chalconata, Microdiscus sp, Hylidae), jenis bangkong (Microhyla achatina, Bufonidae) dan Jenis Kadal (Spenomorphus sp).

2017 Scientiae Educatia: Jurnal Pendidikan Sains

\section{Pendahuluan}

Herpetofauna merupakan suatu komponen ekosistem dan merupakan bagian dari keanekaragaman hayati yang menghuni habitat daratan, perairan hingga pepohonan (arboreal) (Sukiya, 2001). Keanekaragaman hayati di Indonesia memiliki kedudukan yang terhormat di dunia. Indonesia memiliki $16 \%$ jenis reptil dan $9 \%$ jenis amfibi dari seluruh jenis reptil dan amfibi di Dunia. Pada akhir-akhir ini banyak terjadi kerusakan yang terjadi pada cagar alam yang di Indonesia, terbukti dengan data bahwa Kita hanya memiliki kurang dari 2\% daratan dunia (Kantor Menteri Negara Lingkungan Hidup, 2002). Oleh karena itu penelitian ini sangat penting untuk dilakukan guna mengetahui sebaran dan jumlah dari amfibi dan reptil.

Anura memiliki sejarah geologis yang panjang. Mereka barangkali sudah ada pada zaman karbon (340 juta tahun yang lampau), akan tetapi yang bisa dipastikan ialah pada zaman trias (230 juta tahun yang lampau) dengan Genus Triadobatrachus (sinonim Probatrachus). Hewan ini memiliki tengkorak yang serupa dengan Anura masa kini, akan tetapi tubuhnya lebih panjang dan bertulang iga. Vieraella yang berasal dari awal zaman jura (180 juta tahun yang lampau), memiliki kerangka yang sangat mirip dengan bentuk katak sekarang, dan mayoritas diantara family yang kini telah kita kenal sejak 130 juta tahun yang lampau.

Wisata alam pengandaran. Beberapa Jenis amfibi yang sering dijumpai adalah Rhacophorus leucomistx, (katak pohon), Rana limnocharis. Dan Bufo Melanostictus (katak buduk). Sedangkan untuk reptilia yang sering dijumpai adalah Varanus Salvator, Tokek pohon, tentu yang mendominasi adalah beberapa spesies ular (BPLHD Jawa Barat, 2002).

Amfibia merupakan suatu kelas bertulang belakang (Vertebrata) yang mencakup hewan Salamander, Salamander Cacing, Katak dan Bangkong. Istilah amfibia berarti " kehidupan rangkap" yaitu kehidupan yang mencakup cara hidup hewan ini di air maupun di darat.

Seluruh kulit amfibi terlepas dengan alami secara berkala. Semua proses tersebut berkat fungsi fisiologi dari hormonal. Kulit amfibi berbeda dengan kulit reptil yang hanya memiliki satu lapisan, tetapi pada dasarnya pada proses pergantian kulit 
terjadi secara bersamaan. Frekuensi bergantinya kulit bermacam-macam pada spesies yang berbeda. Pergantian kulit pada katak pohon hijau, mungkin terjadi setiap bulan atau lebih. (Sukiya, 2001).

Amfibi memiliki tempat hidup yang selalu berhubungan dengan air. Kebanyakan dari jenis amfibi hanya mampu beradaptasi di iklim yang lembab seperti hutan, untuk menjaga kelembaban tubuhnya karena kulit amfibi digunakan untuk proses pernafasan. Beberapa jenis bisa ditemui di sekitar perairan (sungai dan persawahan), tetapi ada juga jenis amfibi yang hanya bisa hidup jika ada perairan. Pada jenis ini, amfibi akan menuju perairan pada saat musim kawin (Iskandar, 1998).

Amfibia merupakan jenis hewan yang menghabiskan waktu hidupnya di dua alam, darat dan air (semiterrestrial). Sebuah keniscayaan amfibia hidup di dua alam, karena proses perkembangbiakan mereka di air. Telur, yang bermetamorfosis menjadi amfibi muda menghabiskan hidupnya di air sebelum berpindah ke daratan. Siklus hidup tersebut terus berlangsung selama amfibia hidup. Terkadang masalah muncul ketika siklus hidup di dua alam ini terjadi, yaitu mengatur keseimbangan proses pengeluaran dan pemasukan air dalam tubuh. Di dalam air, seperti pada ikan air tawar, pemasukan air secara terus menerus harus dikeluarkan dari glomerulus. Di daratan, air harus dipertahankan, dan untuk ini amfibia mengurangi masukan darah ke glomerulus, dan dengan demikian mengurangi laju filtrasi. Tentu saja, hal ini juga mengurangi aliran darah dari glomerulus ke tubulus. Akan tetapi, fungsi tubulus harus dipertahankan dan peningkatan aktivitas sistem portarenal tambahan memungkinkan hal ini.

Untuk ukuran masa kini, amfibia yang paling awal adalah cukup besar (Diplavertebron), (panjangnya $\pm 60 \mathrm{~cm}$ ), tetapi beberapa hewan yang kemudian ada mempunyai ukuran yang sungguh menakjubkan. Beberapa contoh fosil berukuran +2,5 m. Amfibia ini berjaya selama zaman Karbon. Bumi ditutupi oleh rawa yang luas, kehidupan tumbuhan berlimpah, dan terdapat banyak insekta untuk dimakan oleh Amfibia. Zaman ini sering disebut ( Zaman Amfibia).

Zaman ini diikuti oleh suatu periode (Perm) ketika bumi menjadi lebih dingin dan lebih kering. Penurunan kejayaan amfibia terjadi yang berlangsung terus sampai sekarang. Pada waktu ini hanya tertinggal tiga ordo ialah: (1) Katak dan bangkong (ordo Anura) (2) salamander dan kadal air (newt) (ordo Urodela), (3) Sesilia (ordo Apoda) yang merupakan hewan seperti cacing dan tanpa kaki. Karena tidak mempunyai kulit dan telur yang kedap air, maka tak ada satu amfibia pun yang dapat menyesuaikan sepenuhnya dengan keadaan daratan. (Kimball, 1994)

Lebih dari 2500 jenis amfibia yang masih ada di dunia. Mereka di kelompokkan menjadi 3 yaitu caudata atau urodela (salamander), gymnophionia atau apoda (Caecilia), dan anura (katak dan kodok). Sekarang jumlah kelompok Caecilia sekitar kurang dari 70 jenis dan salamander berjumlah kurang dari 250 jenis, maka kesimpulannya kelompok amfibia yang masih mendominasi yaitu katak dan kodok.

Proses terbentuknya amfibi dewasa melalui siklus metamorfosis yang tidak sederhana karena melibatkan kehidupan di dua alam. Dimulai dari telur $\rightarrow$ berudu $\rightarrow$ amfibi muda $\rightarrow$ amfibi dewasa. Dari proses metamorfosis ini terlahir beberapa jenis amfibi, ada amfibi yang hanya bisa hidup jika ada perairan dan ada amfibi yang bisa hidup walaupun tidak ada perairan. Dalam perkembangannya amfibi yang tidak mempunyai paru-paru sehingga hanya mampu bernafas dengan kulit dan itulah alasanya jika kita melihat kulit amfibi selalu basah.

Banyak jenis vertebrata di dunia, diantaranya pisces, reptilia, aves, dan mamalia. Amfibia merupakan vertebrata yang pertama kali hidup di darat. Jika di amati dari anatomi maka akan terlihat umumnya memiliki pentadaktili, yang pada perkembangan hidupnya bisa saja berubah menjadi tetradaktili atau lainnya (sesuai dengan lingkungannya).

Pisces, reptilia, aves, mamalia, dan amfibia merupakan hewan ektoterm. Hewan ektoterm yaitu hewan yang berdarah panas, artinya suhu tubuh sangat di pengaruhi oleh suhu lingkungannya. Ketika amfibi bertelur, telur-telur mereka biasanya ditinggalkan di perairan (aliran sungai, aliran persawahan, kolam, dll) pada saat telur menetas menjadi berudu, berudu tersebut belum langsung bisa berjalan mereka harus tinggal di air untuk beberapa waktu jika tidak maka mereka mati dan tidak akan berhasil menjadi amfibi dewasa.

Klasifikasi Amfibia

Kelas Amfibia

Sub kelas Apsidospondyli

Superordo Labyrinthodonta

Ordo Temnospondyli

Ordo Anthracosauria

Superordo Salientia

Ordo Proanura

Ordo Anura (katak dan kodok)

Familia Ada 17 familia: Pipidae (tongueless frogs), Discoglossidae (fire-belly dan midwife toads), Rhinophrynidae (burrowing toads), Pelobatidae (spadefoot toads), Leptodacty lidae, Bufonidae (kodok), Rhinodermatidae (mouth-breeding frog), Dendrobatidae, Atelopidae, Hylidae (tree frogs), Centrolenidae, Heleophrynidae, Pseudidae, Ranidae (true frogs), Rhacophoridae, Microhytidae, Phrynomeridae

Subkelas Lepospondyli

Ordo Aistopoda

Ordo Nectridia

Ordo Caudata atau Urodela (salamander) 
Familia Ada 8 familia: Hynobi idae, Cryptobranchidae (giant salamanders), Ambystomidae, Salamandridae (newts), Amphiuraidae, Plcthodontidae (lunglcss salamander), Protcidae (mudpuppies dan olm), Sirenidac

Ordo Gymnophiona atau Apoda

Familia Caeciliidae (Orr, 1976)

Amfibi mempunyai tengkorak yang tebal dan luas secara proporsional, kebalikan dari ikan. Tengkorak amfibi modem mempunyai tulang-tulang premaksila, nasal, frontal, parietal dan skuamosa. Kebanyakan permukaan dorsal dari tubuh Anura tidak seluruhnya tertutup tulang. Bagian dari kondrokranium masih belum mengeras, hanya daerah oksipital dan eksoksipitalnya mengeras, dan masing-masing memiliki kondila bertemu dengan vertebra pertama. Tidak ada langitlangit/palatum sekunder pada amfibi, akibatnya nares internal lebih maju di dalam langit-langit mulut. Di bagian ventral otak ditutupi oleh tulang dermal dinamakan parasfenoid. Gigi ada premaksila, maksila, palatine, vomer, parasfenoid, dan tulang dental. Ada beberapa amfibi yang sama sekali tidak memiliki gigi, atau gigi pada rahang bawah mereduksi.

Dalam hal sistem otot pada amfibi, sebenarnya tidak jauh seperti sistem organ yang lain, sebagian besar merupakan perkembangan dari peralihan keadaan otot ikan dan reptil. Dimana proses sistem otot pada ikan terpusat pada gerakan sisi pinggir, membuka dan menutup insang dan gerakan bersama dua sirip yang sederhana. Maka proses adaptasi di daratan mengubah struktur ini.

Selain itu, sistem otot aksial pada amfibi masih berbentuk metamerik yang mirip dengan ikan, tetapi jelas terlihat perbedaan-perbedaannya. pembatas yang sejajar membagi otot bagian punggung dan otot bagian bawah. Bagian dari sistem otot bagian punggung (dorsal) dapat mempengaruhi gerakan kepala, Otot bagian bawah (ventral), merupakan bukti dalam pembagian sistem otot-otot setiap bagian organ tubuh amfibia.

Bagian-bagian otot yang ada pada amfibi yaitu otot bagian luar, otot bagian dalam dan otot bagian punggung, otot bagian punggung sangat sedikit dibandingkan dengan lainnya. Gerakan-gerakan yang dilakukan oleh amfibi merupakan gerakan dari perpaduan antara otot-otot yang bersinergi. Misalnya gerakan, berenang, meloncat, berjalan, atau memanjat melibatkan beberapa otot yang bekerjasama dan bersinergi. Beberapa di antaranya terdapat pada seluruh kakinya yaitu otot dari pangkal paha kebawah dan beberapa otot dalam (Kardong, 1998).

Pada kenyataannya amfibi memiliki banyak masalah dalam menghantarkan darah keseluruh tubuh melalui jantung, ini dihadapi oleh sebagian besar amfibi. Untuk mengisi dan memompa darah dari jantung dan memisahkan antara darah yang mengandung oksigen dan darah yang tidak mengandung oksigen. jantung memiliki pembatas intersisial, ruang ventrikular, dan ruang konus arteriosus yang terdapat pada dua pembuluh, Darah dari tubuh masuk ke bagian atrium kanan dari sinus venosus kemudian masuk ke ruang kanan ventrikel, sehingga dipompa jantung ke paru-paru. Darah yang banyak mengandung oksigen dari paru-paru masuk ke ruang jantung (atrium kiri) lewat pembuluh vena pembalik kemudian menuju sisi ruang kiri ventrikel dan selanjutnya dipompa menuju ke seluruh tubuh. Beberapa pengecualian pada ordo urodela (salamander) yang tidak mempunyai paru-paru, di mana terdapat celah intersisial tidak lengkap dan tidak memiliki pembuluh vena pulmonalis.

Sebagian besar amfibia pada pasangan arkus aorta pertama, kedua dan kelima hilang. Berikut ini arkus aorta yang dimiliki oleh amfibia: Arkus aorta ketiga; terdapat pada sisi dasar carotid internal, arkus aorta keempat; memiliki fungsi yang menyambungkan system arkus menuju ke posterior berupa dorsal aorta, arkus aorta cabang (Bagian proksimal dari pasangan keenam); yang berfungsi membawa darah dari arteri pulmokutaneus menuju ke paru-paru dan ke kulit di mana proses aerasi terjadi. Sistem pembuluh vena pada amfibi hampir mirip dengan sistem pembuluh vena pada ikan, terkecuali pada pembuluh vena abdominal yang masuk di portal hepatik ke sinus venosus (Storer, Et, al. 1983)

Dalam proses pencernaan makanan katak memerlukan ludah, tetapi tidak terlalu memerlukan sekret di mulut. Alat tubuh yang menghasilkan getah/sekret biasanya banyak di hasilkan oleh amfibia. Organ tubuh tersebut adalah lidah, yang fungsinya untuk menangkap makanan.

Amfibia selain menghasilkan getah/sekret juga menghasilkan getah intermaksiari yang terdapat di dinding mulutnya. Pada perkembangannya amfibi berkembang dengan beradaptasi pada lingkungannya, sebagian besar amfibi tidak memiliki lidah yang bisa digerakkan dan ada yang bisa dikeluarkan untuk menangkap mangsa. Diatas telah disebutkan bahwa ada beberapa kelompok amfibia, maka secara anatomi mereka otomatis berbeda. Ada yang ususnya pendek dan panjang, karena usus menunjukkan variasi diantara amfibi. Pada jenis Caecilia memiliki usus yang tidak bisa dibedakan antara usus kecil dan usus besar sedangkan pada jenis anura memiliki jenis usus yang panjang, terakhir adalah kloaka yang berfungsi untuk ekskresi feses dan perkembangbiakan

Selama tahap larva sebagian besar amfibi bernafas dengan insang. Insang ini bukan tipe internal se perti pada ikan, tetapi insang ektemal. Struktur insang luar adalah filamenous, tertutup epitelium bersilia, umumnya mereduksi selama metamorfosis. Beberapa amfibi berekor, insang luar ini ada selama hidupnya.

Masalah fisiologis dari metamorfosis amfibi yang berubah dari kehidupan larva aquatik ke kehidupan katak dewasa di darat, memang menarik untuk dipelajari. Umumnya pada larva akuatik, kadar hemoglobin lebih rendah sebagai akibat sedikitnya sirkulasi eritrosit sehingga insang lebih efisien, sebab secara umum aktivitas di lingkungan air lebih sedikit dibandingkan di daratan.

Struktur paru-paru pada amfibi masih sederhana, Amfibi yang hidup di air, permukaan dalam dari paru-paru lembut, tetapi sebagian besar dinding paru-paru pada katak dan kodok berisi lipatan alveoli sehingga meningkatkan permukaan pernafasan, Beberapa amfibi dari ordo Caudata memiliki trakhea pendek, disokong oleh kartilago yang terbagi dalam dua 
cabang yang membuka ke arah paru-paru. Ujung dari trakhea satu atas diperluas, khususnya pada katak dan kodok, untuk membentuk larink atau voicebox (sakus vocalis = kotak suara), dimana pita suara berada. Pertemuan antara farink dan larink disebut glotis. Pada umumnya udara dipompa ke dalam paru-paru melalui proses yang sederhana. Sebagian besar amfibi bernafas melalui kulit, tetapi salamander ketika dewasa mendapatkan oksigen melalui kulit dan epitelium oral. Oleh sebab itu berarti kulit harus dijaga kelembabannya. Amfibi darat dalam menjaga kelembaban tubuh ini dilengkapi dengan sejumlah kelenjar mukus yang didistribusikan di permukaan tubuh.

Ginjal amfibi, seperti pada ikan sejenis opistonefros. Amfibi berekor ginjalnya berstruktur elongasi seperti pada Elasmobranchii tetapi pada jenis Anura ada tendensi menjadi pendek. Banyak amfibi sebagian atau seluruh hidupnya berada dalam air, korpuskel renalis berkembang untuk membantu mencegah pengenceran yang berlebihan dari cairan tubuh. Pembuluh arkinefiik amfibi jantan berupa genital ekskretori. Pembuluh arkinefrik tersebut han ya melakukan transport sperma (Storer, Et, al. 1983).

Bangsa amfibia, kantung kemihnya telah berkembang dari bentuk peralihan yang ditemui pada ikan merupakan hasil perkembangan kandung kemih dari ujung pembuluh arkinefiik yang letaknya jauh dari pusat sehingga melewati pembuluh ginjal menuju kloaka, setelah itu ke kantung/penampung urin. Berbeda dengan amfibi yang biasa hidup di daratan air kemih yang terkumpul dipenampung urin akan diserap kembali guna mengatur dan mengimbangi kelembaban kulit yang kurang, karena kulit membantu dalam proses pernafasan. Jenis amfibi darat banyak menghabiskan waktu di daratan, biasanya pada rongga-rongga kecil tanah atau batuan, seperti spadfoot toad (scaphious). Spadfoot toad memiliki kemampuan untuk menyerap air tanah lebih besar daripada jenis lainnya dengan cara osmosis yang terjadi pada kulitnya (dinding sel atau tekanan selaput kulitnya lebih besar daripada tekanan cairan yang ada di sekitarnya sehingga cairan dapat masuk secara otomatis).

\section{Metode Penelitian}

Penelitian ini dilakukan di Jawa Barat tepatnya di Wisata Alam dan Cagar Alam Pangandaran. pengambilan data dilakukan dua hari berturut-turut pada bulan Juni 2015. peralatan yang digunakan dalam penelitian ini adalah alti meter, jangka sorong, penggaris, stick, herpetnet, kantong blacu, plastik sampel, botol spesimen, kuadrat ukur.

Lokasi ditentukan berdasarkan peta lokasi kawasan dan informasi hasil survey. Lokasi penelitian meliputi: daerah aliran sungai daerah Cikamal dan Cirengganis pengambilan sampel menggunakan VES (Visual Encounter Survey) yaitu mencari herpetofauna dengan menyusuri jalur yang telah ditentukan sepanjang $400 \mathrm{~m}$ untuk menangkap herpetofauna yang terlihat.

Identifikasi jenis-jenis herpetofaura : (1). Fotografi Spesimen; Pengambilan gambar spesimen dilakukan sebelum dan sesudah penangkapan dengan menggunkan kamera digital, (2). Identifikasi dan preparasi specimen; Mengidentifikasi sampel herpet yang didapat dan merapikan spesimen untuk dipreparasi sehingga dapat dibawa ke Jakarta. pengolahan data: (1). Perhitungan jumlah, (2). Perhitungan persentase hasil penelitian.

\section{Hasil dan Pembahasan}

Tabel 1 jenis herpet dan frekuensi perjumpaannya

\begin{tabular}{|c|c|c|c|c|c|c|}
\hline \multirow[b]{2}{*}{ No } & \multirow[b]{2}{*}{ Nama Herpet } & \multicolumn{2}{|c|}{ Waktu Pengamatan } & \multirow[b]{2}{*}{ Frek } & \multirow[b]{2}{*}{ Total } & \multirow[b]{2}{*}{ Keterangan } \\
\hline & & $\begin{array}{l}26 \text { Juni } \\
2015\end{array}$ & $\begin{array}{l}27 \text { Juni } \\
2015\end{array}$ & & & \\
\hline 1. & $\begin{array}{l}\text { Katak (Fajervarya } \\
\text { limnocharis) }\end{array}$ & $\sqrt{ }$ & & 2 & 2 & di sekitar aliran sungai, Cirengganis \\
\hline 2. & $\begin{array}{l}\text { Katak Sawah } \\
\text { (Rana chalconata) }\end{array}$ & & $\sqrt{ }$ & 1 & 1 & $\begin{array}{l}\text { Semak-semak di lokasi dekat air terjun, } \\
\text { Cikamal }\end{array}$ \\
\hline 3. & $\begin{array}{l}\text { Bangkong sedang } \\
\text { (Microdiscus } s p \text { ) }\end{array}$ & $\sqrt{ }$ & & 2 & 2 & Ditangkap di area jalan setapak, Cirengganis \\
\hline 4. & $\begin{array}{l}\text { Kadal } \\
\text { (Spenomorphus sp) }\end{array}$ & $\sqrt{ }$ & & 1 & 1 & $\begin{array}{l}\text { Ditangkap dekat aliran sungai di balik batu- } \\
\text { batuan, Cikamal }\end{array}$ \\
\hline 5. & $\begin{array}{l}\text { Katak pohon } \\
(\text { Hylidae })\end{array}$ & & $\sqrt{ }$ & 1 & 1 & Di sekitar aliran sungai, Cikamal \\
\hline 6. & $\begin{array}{l}\text { Katak (Microhyla } \\
\text { achatina) }\end{array}$ & $\sqrt{ }$ & & 1 & 1 & Di sekitar aliran sungai, Cirengganis \\
\hline 7. & $\begin{array}{l}\text { Bangkong } \\
\text { (Bufonidae) }\end{array}$ & & $\sqrt{ }$ & 1 & 1 & $\begin{array}{l}\text { Di sekitar aliran sungai dekat pohon-pohon, } \\
\text { Cikamal }\end{array}$ \\
\hline
\end{tabular}


Pada penelitian herpetofauna kali ini bertujuan untuk mengetahui jenis herpetofauna yang sering muncul di daerah Cikamal dan Cirengganis. Dua daerah tersebut dipilih karena karena herpetofauna hidup didaerah air yang tawar. Sungai merupakan salah satu tempat habitat yang ideal untuk pencarian herpetofauna (Mistar, 2002). Pada penelitian kali mendapatkan 11 jenis herpetofauna yang terdiri dari 6 jenis amfibi dan 1 jenis reptil di dua lokasi tersebut. Jenis reptil yang ditemukan adalah Kadal (Spenomorphus sp). Sedangkan untuk amfibi di temukan (Fajervarya limnocharis, Rana chalconata, Microdiscus sp, Hylidae, Microhyla achatina, Bufonidae).

Perbandingan dua daerah pengamatan tersebut memiliki tipe habitat yang berbeda yaitu pada daerah Cirengganis memiliki tajuk hutan yang terbuka dengan vegetasi pandan, palem, dan fikus dan daerah aliran sungai Cirengganis bermuara dilaut jarak daerah sangat dekat sekitar 50 meter dari muara dan memiliki air yang agak payau. Pada daerah aliran sungai Cikamal memiliki tutupan tajuk yang besar di bandingkan daerah Cirengganis dengan tipe vegetasi yang terbanyak adalah bayur dan jati. Sungai Cikamal terletak sekitar 500 meter dari muara dan laut. Dan lebar sungai yang tergenang air 3,5 meter. Perbedaan inilah yang dapat mempengaruhi keanekaragaman di dua daerah tersebut. Keragaman tumbuhan atau habitat dan letak daerah pengamatan dengan laut dapat mempengaruhi keberagaman herpetofauna (Kusrini, 2009).

Hasil penelitian perbandingan jenis herpetofauna di cagar alam dan taman wisata alam pengandaran Jawa Barat (Herpetologi), dari 9 ekor jumlah herpetofauna yang ditemukan dan telah di identifikasi, didapat 2 jenis herpetofauna yaitu: (amfibi dan reptil). Untuk amfibi terdiri dari: 1. jenis katak, 2 jenis bangkong. Masing masing perbandingannya sebagai berikut; jenis katak dengan jumlah 5 ekor sebesar (55,55\%), jenis bangkong dengan jumlah 3 ekor sebesar (33,33\%) sedangkan untuk reptil: hanya ditemukan jenis kadal dengan jumlah 1 ekor sebesar $(11,11 \%)$.

Sedangkan dari jenis amfibi di klasifikasikan menjadi 2 jenis (katak dan bangkong); katak, yaitu katak (Fajervarya limnocharis), katak sawah (Rana chalconata), katak pohon (Hylidae Sp), dan katak (Microhyla archatina). Perbandingannya katak (Fajervarya limnocharis) dengan jumlah 2 ekor (22,22\%), katak sawah (Rana chalconata) dengan jumlah 1 ekor $(11,11 \%)$, katak pohon (Hylidae Sp) dengan jumlah 1 ekor $(11,11 \%)$, dan katak (Microhyla archatina) dengan jumlah 1 ekor $(11,11 \%)$. Jenis bangkong sedang (Microdiscus $\mathrm{sp}$ ) dengan jumlah 2 ekor $(22,22 \%)$ dan jenis bangkong (Bufonidae) dengan jumlah 1 ekor $(11,11 \%)$. Jenis kadal (Spenomorphus sp) dengan jumlah 1 ekor $(11,11 \%)$.

Dapat disimpulkan dari data yang diperoleh 5 ekor $(55,55 \%)$ jenis katak yang diidentifikasi yang lebih banyak daripada jumlah herpetofauna lainnya yaitu jenis bangkong dengan jumlah 3 ekor $(33,33 \%)$ sedangkan untuk jenis kadal dengan jumlah 1 ekor $(11,11 \%)$.

\section{Simpulan}

Berdasarkan hasil penelitian dapat disimpulkan bahwa terdapat 2 Jenis herpetofauna (amfibi dan reptil). Amfibi (katak dan bangkong) dan reptil (kadal). Herpetofauna yang ditemukan yang berjumlah 9 ekor yaitu : Katak (Fajervarya limnocharis) berjumlah dua ekor, Katak Sawah (Rana chalconata) berjumlah satu ekor, Bangkong sedang (Microdiscus sp) berjumlah dua ekor, Katak pohon (Hylidae) berjumlah satu ekor, Katak (Microhyla achatina), berjumlah satu ekor, Bangkong (Bufonidae) berjumlah satu ekor dan Kadal (Spenomorphus sp) berjumlah satu ekor.

\section{Daftar Pustaka}

Arikunto, Suharsimi. (2002). Prosedur Penelitian suatu Pendekatan Praktik, Jakarta: PT Rineka Cipta.

Arikunto, Suharsimi. (2003). Manajemen Penelitian, Jakarta : PT Rineka Cipta

Atlas Flora dan Fauna Indonesia, (2001). Badan Koordinasi Survei dan Pemetaan Nasional (BAKOSURTANAL). Jakarta: PT Gramedia

Budiarto, Eko. (2004). Metodologi Penelitian Kedokteran. Jakarta : PT EGC.

Campbell.,N.A; LG. Mitchell, J,B. Reece. (2000). Biology: Concepts and Connections. Third Edition. Sanfransisco: Wesley Longman Inc.

Hicman, C.P.; L.S. Roberts and A. Larson. (1998). Biology of Animals. Boston: The McGraw-Hill Companies, Inc

Hildebrand, M. (1995). Analysis of Vertebrata Structure. Fourth Edition. New York: John Wiley \& Sons, Inc

Kardong, K.V. (1998). Vertebrates: Comparative Anatomy, Function, Evolution. Second Edition. Boston: The McGraw-Hill Companies, Inc

Lan, T.S. (1980). Tiga Ekosistem (Lingkungan Hidup Pohon Beringin, Lingkungan Hidup Sungai Kecil di Hutan, dan Lingkungan Hidup Pohon Bakau). Bogor: Yayasan Indonesia Hijau.

McFarland, W.N.; F.H. Pough; T.J. Cade and J.B. Heiser. (1985). Vertebrate Life. Second Edition. New York: Macmillian Pub. Co

Miller, S.A. and J.B. Harley. (1999). Zoology. Fourth Edition. Boston: The McGraw-Hill Companies, Inc.

Odum, E.P. (1999). Dasar-Dasar Ekologi. (Terjemahan: Tjahyono Samingan). Yogyakarta: Gadjah Mada University Press.

Orr, R.T. (1976). Vertebrate Biology. Philadelphia: W.B. Saunders Company.

Redaksi Ensiklopedia Indonesia, (1988). Ensiklopedi Indonesia Seri fauna Reptilia dan Amfibia. Jakarta: PT Dai Nippon Printing Indonesia

Storer, T.L.; R.L. Usinger; R.C. Stebbins and J.W. Nybakken. (1983). General Zoology. New York: McGraw-Hill Companies, Inc. 
Sukiya, (2001). Biologi Vertebrata. Yogyakarta: Universitas Negeri Yogyakarta

Wirjosoemart, Koesmadji, dkk. (2000). Teknik Laboratorium, Bandung: Universitas Pendidikan Indonesia Press. 